\title{
GONDOLATOK A BÜNTETÉS-VÉGREHAJTÁSI JOG SZEREPÉRŐL
}

\section{IDEAS ABOUT THE ROLE OF PRISON LAW}

\author{
Vókó György \\ az MTA doktora, professor emeritus, igazgató, \\ Országos Kriminológiai Intézet
}

\begin{abstract}
ÖSSZEFOGLALÁS
A tanulmány a Magyarországon és Európa-szerte megváltozott büntetés-végrehajtási jog szerepe felismerésének elméleti és gyakorlati jelentőségére kívánja felhívni a figyelmet, miszerint mindez folyamatosan teljesedik ki a társadalmi akarat, a gyakorlati igények és az ezek feldolgozására kész tudomány, a megnövekedett emberi jogi nemzetközi elvárások talaján. Vizsgálja, hogy ennek a reneszánszát élő tevékenységnek van-e már mérhető hatása a visszaeső bűnözés elleni komplex küzdelemben, és melyek a főbb irányai? Abból indul ki, hogy valamennyi büntetőjogi szankció - amelyek tartalma jogkorlátozás - végrehajtásának szabályozását tartalmazó büntetés-végrehajtási jog jogállamban elismerten érdemi részét képezi az egész büntető felelősségre vonás folyamatának.
\end{abstract}

\section{ABSTRACT}

The study attempts to draw attention to the theoretical and practical importance of recognizing the changing role of prison law in Hungary and across Europe, to interpret how this development operates on the grounds of social will, practical needs and permanently developing science as well as due to the increased importance of international human rights standards. It also examines whether this renaissance of the activities in prison-law has a measurable impact on the complex fight against recidivism, and if yes, which can be titled as the main directions. The study assumes that the enforcement of criminal law (which naturally involves the element of the limitation of rights) naturally represents a substantive part of the whole process of prosecution in the constitutional state.

Kulcsszavak: büntetés, büntetőjogi felelősségre vonás, garanciarendszer, büntetés-végrehajtási jog, visszaeső bűnözés, elítéltek jogi helyzete, büntetés utóélete, törvényesség, jogállamiság

Key words: penalty, criminal prosecution, guarantee system, prison law, recidivism, legal position of convicted people, follow-up of the penalty, legality, constitutional law 


\section{BEVEZETÉS, ELŐZMÉNYEK}

A büntető tudományok fejlődésútja jól mutatja, miként változtak a büntetési célokra vonatkozó felfogások, a büntetőpolitikai szemlélet, maga a büntetőjog és intézményei. Ennek a rendszernek része a büntetés-végrehajtás jogi szabályozása, az elítéltek jogi helyzete.

A bünözés mint társadalmi jelenség és a bünelkövetés mint egyedi magatartás ősidők óta foglalkoztatja az embereket.

A büntetés minden korban szorosan összefüggött a társadalomfelfogással, valamint a mindennapi élet körülményeivel. Régi felismerése az emberiségnek, hogy a bün által megbomlasztott jogi egyensúlyt a büntetés hivatott helyreállítani.

A büntetésnek visszatartó ereje van, a törvényes és humánus büntetés-végrehajtás pedig hozzájárulhat a bünözés csökkentéséhez. A kriminalitás okainak komplex elemzése, a hatékony eszközök és módszerek keresése folyamatos feladat. A fejlődés azonban nehezen képzelhető el a tudomány és a gyakorlat jó együttmüködése nélkül.

A büntető anyagi és eljárási tételes jognak csakúgy, mint a bünügyi tudományoknak fö küldetésük az ember tisztelete, akkor is, amikor a sértett védelmére siet, de akkor is, amikor az elkövetőt szankcióval sújtja. Ebben az összefüggésben különös felelőssége van a büntetés-végrehajtási jogtudománynak, amelynek elméleti fundamentumai összecsengenek az anyagi és eljárási dogmatika tételeivel, de nem azonosak azokkal.

A büntetés-végrehajtási jog a büntetőjog és a büntetőeljárási jog nélkül „vak”, viszont azok nélküle „parttalanná”, önmagukért valóvá válnak. Edward Livingstone már lassan kétszáz éve hangsúlyozta, hogy a börtönök szervezetétől és igazgatásától függ az egész büntetőrendszer sikere. A bíróság „csak” megállapítja a büntetés nemét és mértékét, de hogy a célját elérje a büntetés, az az elítélt egyéniségén túl a végrehajtás módján is múlik. Vagyis a büntetés egy forma, aminek tartalmat a végrehajtás ad.

„Hiába az anyagi jog tudományos müvelése, a büntetésről vallott teóriák kidolgozása és hirdetése, a kiszabás elveinek kidolgozása, ha minden elképzelések megbuknak a diszfunkcionális végrehajtáson" - fogalmazta meg az 1800-as évek első felében a haza bölcse, Deák Ferenc, tiszti ügyészi tapasztalatait rögzítve (Vókó, 1996; 1999). ${ }^{1}$

A 19. század végén Balogh Jenő akadémikus, elnök nem győzte eléggé hangsúlyozni, hogy „A börtönök rendezetlen állapotában a közbiztonságra, magára a társadalomra és az államra óriási veszélyek leselkednek, mert a szabadságvesztés

\footnotetext{
${ }^{1}$ Deák Ferenc az 1840. évi Országgyűlés után megyéje (Zala vármegye) gyűlésén többek között ezt is elöadta, amit 1841-ben a Pesti Hirlap is megörökített.
} 
büntetés, ha nem kellően hajttatik végre, alig más, mint gonosztevők iskolája" (Balogh, 1888).

A büntető-végrehajtás tárgya 1882-ben a római egyetemen önálló tanszéket kapott, amivel tudományági önállóságának hangoztatása megkezdődött. Ma már az általános jogi müveltséghez tartozik, hogy a büntetés-végrehajtási életviszonyokat szabályozó jogot a büntető anyagi és eljárási jog mellett önálló, harmadik jogterületnek tekintik. Az Európában is egyértelmúen uralkodó felfogás szerint a büntetés harmadik pilléreként említik a büntetés-végrehajtási jogot, a büntetés-végrehajtási hatóságot. Határozottan kifejezésre jutott ez Günther Kaiser német jogtudós írásából vagy például a francia és a német törvényekböl is.

Magyarországon Angyal Pál, Finkey Ferenc és Irk Albert már a 20. század elején rámutattak arra, hogy a büntetés-végrehajtással kapcsolatos kérdések önálló szabályozást igényelnek. Irk Albert már akkor magától értetődő természetességgel osztotta fel a büntetöjogot a ma is követett három fö részre: anyagi, eljárási és végrehajtási jogra. A rendszerváltozással és a jogállamiság követelményeinek teljesítésével „alkotmányos rangra” emelkedett, jogi szakvizsgatárgy, majd az egyetemeken kötelező tantárgy lett.

Az új évezredben, évszázadban a világ legnagyobb részén felértékelődött a büntetés-végrehajtási jog. Magyarországon is először a büntetések és az intézkedések végrehajtásáról szóló 1979. évi 11. törvényerejű rendelet útján, majd a jogállami követelményekkel harmonizáló 1993. évi XXXII. törvény általi módosításával és kiegészítésével. A 2013. évi CCXL. törvény pedig már megfelelő magasságra emelte a korszerủvé vált büntetés-végrehajtási jogot.

Kiemelhető, hogy a büntetés-végrehajtási jog szabályozása Magyarországon és Európa-szerte megújult vagy változik, szinte reneszánszát éli. A jelen és a jövő emberközpontú büntető igazságszolgáltatása szempontjából a büntető anyagi és eljárási jogi szankcionálás feltételei és formái mellett fontos a büntetés-végrehajtási jog is.

Az európai jog befolyását érzékelhetjük minden bünügyi területen. Ezt az Európai Ügyészek Konzultatív Tanácsa is különösen figyelembe vette az Európa Tanács Miniszteri Bizottságának az Európai Börtönszabályokról szóló, tagállamokhoz intézett Rec (2006) 2. ajánlásának alkalmazását elősegítő külön iránymutatásában (Polt-Vókó, 2012).

\section{A VÉGREHAJTÁS HATÁSA AZ ELITTÉLTEK JOGI HELYZETÉRE}

A bűnelkövetés nem maradhat következmények nélkül. A büntetőjogi felelősségre vonás a legsúlyosabb szankció, ezért a hatékonyság és a törvényesség kérdései e területen jelentkeznek a legélesebben. 
A büncselekményre adott válasznak tiszteletben kell tartania a büntetőjog és büntetés-végrehajtási jog társadalmi funkcióját, a társadalom védelmét, és igazodnia kell ezek hagyományos értékeihez és a jogállamiság megkívánta feltételekhez.

A büntető felelősségre vonás harmadik, azaz végrehajtási szakaszában valósul meg a jogerős ítéletben vagy más hatóság határozatában megjelölt büntetőjogi szankció, büntetőeljárási jogi kényszerintézkedés vagy más hatósági szankció, mégpedig a törvényben meghatározott mértékben és határig. Alapvető jogok korlátozásáról van szó, ezért messzemenő védelmet kell nyújtani, amit a széles körü garanciarendszer hivatott biztosítani. Az elítéltet csak az ítéletben és a törvényben meghatározott joghátrányok érhetik.

Az emberi jogok megnövekedett jelentősége szükségszerủen vetette fel azt az igényt, hogy újraértékeljük a bünelkövetők jogi helyzetét (jogaikat és kötelezettségeiket), ezek érvényesítésének módját, az ezt szabályozó büntetés-végrehajtási jog feladatát.

Az elítéltek jogi helyzete szintjelzője a jogállamiságnak. A minden állampolgárt megillető jogok és kötelezettségek annyiban érvényesülhetnek, amenynyiben nem ellentétesek a büntetés céljával, aminek konkrét tartalmat a büntetés-végrehajtás jogszabályai adnak. Valamennyi felelősségre vonás hatálya alatt álló egyén jogi helyzetének ez a legérzékenyebb pontja, itt kell megtalálni az optimális határt: a jogokat kizárólag olyan mértékben korlátozni, amilyen mértékben a törvények megengedik. Nemcsak a jogok deklarálásáról van szó, hanem azok gyakorolhatóságáról is. Az állampolgári jogok egy része szünetel a végrehajtás alatt, más része korlátozottan, újabb része korlátlanul érvényesül. A kifejezetten büntetés-végrehajtási jogok és kötelezettségek sajátossága, hogy csak a végrehajtási idő alatt hatályosulnak, annak lejártával pedig aktualitásukat vesztik. A büntető és igazgatási felelősségre vonás hatálya alá került személyek jogainak biztosítása a jogi egyensúly helyreállítása mellett a jogszabályokat tisztelö társadalomba visszavezetés céljának elérését segíti elö. Társadalmi, jogállami alaptörvényi igény, hogy a bünelkövetőktől meg kell védeni a többi embert - embertársainak ugyanolyan és éppúgy tiszteletben tartandó szabadságába és jogaiba nem ütközhet senkinek a magatartása -, ugyanakkor a bünelkövetés szankcionálását jelentő jogkorlátozásnak meg kell felelnie az emberi jogok védelmével kapcsolatos garanciális elvárásoknak, a törvényesség követelményének (Belovics, 2008).

A büntető felelősségre vonás e szakaszában már a tettesre esik nagyobb figyelem. A humanitás minden büntetőpolitikát megelőző tétele azt kívánja meg, hogy a bủncselekmény elkövetöje és a megsértett közösség között létrejött kapcsolatoknak legyen része az elmarasztalás, csakúgy, mint a jogtisztelő társadalomba történő visszatérés, az integráció elősegítése. 


\section{A VISSZAESŐ KRIMINALITÁST CSÖKKENTŐ SZEREPRŐL}

Magyarországon az utóbbi két évtizedben a regisztrált bünelkövetők számának csökkenésével párhuzamosan abszolút számát és arányát tekintve is csökkent a büntetett előéletủ bünelkövetők száma és aránya. Ugyanez látszik a regisztrált többszörös vagy erôszakos visszaeső bủnelkövetők és a visszaeső bünelkövetők számarányából. Az egy-egy évben előforduló kisebb emelkedés az irányt nem változtatta meg (az 1995. évi 121 000-hez képest 2017-ben már alig több mint 90000 bűnelkövetőt regisztráltak a hatóságok), és a legfrissebb ENyÜBS ${ }^{2}$ adatok szerint a büntetett elóéletüek aránya is csökkent az évek során (az 1995. évi közel 37 százalékról 25 százalék alá). A büntetett előéletűek egymáshoz viszonyított aránya viszont csak 15 százalékkal, utóbbiak közül a többszörös vagy az eröszakos többszörös bünelkövetők aránya 5 százalékkal nőtt. 2018-ra a fogvatartottak közötti arány is közel másfél százalékkal nőtt. Az OBH 2017-es adatai ${ }^{3}$ szerint a szabadságvesztéssel és közérdekủ munkával sújtottak között majdnem 20 százalékkal több a visszaeső, mint az összes többi büntetési nem tekintetében. A 90-es évek második felében még a visszaeső bünelkövetők közel fele többszörös visszaeső volt, az ENyÜBS adatai szerint ez az arány napjainkra 38 százalékra csökkent.

Ha a büntetés-végrehajtási intézetekben fogvatartottak összetételét nézzük a visszaesés szempontjából, akkor ezektől eltérő arányokról kapunk képet. ${ }^{4}$ Az első bűntényesek és a bünismétlők (visszaesők és ezen idő előtti bünelkövetők) itt fele-fele arányban oszlanak meg, egy-két százalékkal nagyobb a már korábban büncselekményt elkövetők aránya. A szabadságvesztés büntetést töltő elítéltek súlyosabb megítélésü büncselekményt követtek el, mint a nem szabadságelvonást tartalmazó büntetéssel sújtottak, az ő visszaesési mutatóik az összes visszaeső mutatóinak kétszerese. Közülük mintegy 35 százalék a többszörös vagy erőszakos többszörös visszaesők aránya. A fogvatartottak közül kiszámíthatóan mintegy 43 százalék körüli a már - életében valamikor, tehát nem a visszaesési időn belül - korábban büncselekményt elkövetett személy.

Mindezek az adatok azt mutatják, hogy a súlyosabb megítélésủ büncselekményeket elkövetők a többi bünelkövetöhöz viszonyítva erőteljesebben növelik a bünelkövetői utánpótlást. Tehát velük kapcsolatban kell megtalálni az eddigieknél hatékonyabb módszereket, amelyek a jövőben bennük is erősíthetik a törvénytiszteletet. A „bünözők szabadsága” és a mások szabadsága közötti harc a világon mindenhol aggasztja a társadalmat. Az USA-ban már szigorítottak is a végrehajtási módszereken.

\footnotetext{
${ }^{2}$ Egységes Nyomozó Hatósági és Ügyészségi Bűnügyi Statisztikai Rendszer.

${ }^{3}$ Országos Bírósági Hivatal: Jogerősen befejezett büntetőeljárások vádlottjainak statisztikai adatai.

${ }^{4}$ Börtönügyi Statisztikai Szemle 2015, 2016, 2017, 2018. és 2019. évi 1. számai.
} 
Magyarországon tehát összességében a bünelkövetők számának csökkenését lehet látni, viszont az ismételt bünelkövetők - beleértve azokat is, akik mentesültek már a büntetéshez füződő hátrányos jogkövetkezmények alól, avagy a nyilvántartásból is törölték már öket, de ismét büncselekményt követtek el - aránya nem látszik olyan figyelemre méltóan csökkenőnek az ENyÜBS adatok és egyéni felmérésem szerint. Hasznossággal bírna a jövőben a bünügyi nyilvántartó hatóság kutatást támogató odafigyelése és lehetősége - természetesen a személyes adatvédelemre vonatkozó rendelkezések megtartásával - az ismétlődő, tehát több mint a Btk. szerint visszaesőnek tekintendő büncselekmények elkövetőire.

\section{CÉLOK ÉS MÓDSZEREK A HATÉKONYSÁG JEGYÉBEN}

A büntetésnek létezik egy pozitív utóélete, ami nemcsak átmeneti, hanem tartósnak bizonyul, és a büntetésüket letöltött elítéltek nagyobb része nem válik ismételten bünelkövetővé.

A szankciórendszer sikerében a büntető felelősségre vonás valamennyi szakaszának szerepe van, de komoly felelösséget vállal a végrehajtás és a szankció utóélete is. Ugyanakkor az újabb bünelkövetésnek lehetnek olyan szociálpszichológiai vagy környezeti okai, amelyek közömbösítik vagy lerontják a pozitív hatásokat.

A büntetés célja a büncselekménnyel megbomlott jogrend helyreállítása, de ennek része a reintegráció. A büntető norma tekintélyét nem csupán a büntetés, hanem a nyomában járó megjavulás is erősíti. A francia büntetés-végrehajtási törvény 1. cikkében leszögezte: „A szabadságvesztés büntetés-végrehajtási rezsimje összebékíti a társadalom védelmét, az elítélt megbüntetését és a sértett érdekeit a fogvatartott társadalmi beilleszkedésének vagy a reintegrálásának szükségességével annak érdekében, hogy az érintett felelősségteljes életet élhessen és megelőzhető legyen újabb bűncselekmény elkövetése." ${ }^{5}$ A cél tehát röviden és általánosan fogalmazva nem lehet más, mint a szankciók hatékonyságának növelése, és az elítélt visszailleszkedésének segítése.

Az egyes államok élnek azzal a lehetőséggel, hogy az elítéltek kedvező magatartásváltozásait a szankciók enyhítése kíséri. Mind nagyobb teret nyernek a szabadságvesztés alternatívái, például a nyomon követhetőség, az elektronikus felügyelet, a feltételes szabadság, a bezártság rövidítése. Felmerülhetnek olyan kérdések, hogy megfelelőek-e a végrehajtási szabályok, mennyire távolodhat el az elviselt ítélet a meghozott ítélettől, milyen hatása lehet majd ennek a büntetéskiszabásra. A büntetés enyhítése nem járhat a szankcióval fenyegetés visszatartó erejének csökkenésével.

\footnotetext{
${ }^{5}$ A 2009. november 24-i 2009-1436. számú francia büntetés-végrehajtási törvény 1. cikke (URL1).
} 
A gyakorlati kérdések felismerése a tudomány múvelőit, a jogalkotókat, jogalkalmazókat és a jogkövetőket a szakmai kérdések legjobb megoldására ösztönzik. „A gyakorlat és az elmélet egymásra utalt [...] a gyakorlat problémái generálják az elmélet kutatási irányait, az elmélet pedig - lássuk be - korlátozott hatékonysággal képes fejleszteni a gyakorlatot" (Korinek, 2010).

A tudomány és a gyakorlat együttmüködése nélkül nehezen képzelhető el további előrelépés. Az elmélet és a gyakorlat szorosabb összetartozásán munkálkodni kell. Közös érdekünk, hogy széles hidat találjunk napjaink elmélete és gyakorlata között, amelyre a jövő büntetés-végrehajtási joga épülhet.

Megalapozott tudományos törekvés, hogy a büntetőeljárás megindulásától az utógondozás megszűnéséig tartó folyamatot mint egységes egészet vizsgáljuk, ami a társadalommal összeütközésbe került személyt hivatott a társadalomba visszavezetni.

A büntetés-végrehajtásra hatást gyakorló értékek komplex kidolgozása több tudományág együttmüködésével tűnik reálisnak. Még jól müködő büntetési rendszer esetén sem hagyhatók figyelmen kívül a társadalmi beilleszkedés objektív feltételei, valamint a társadalmi viszonyok, amelyek kedvező alakulása hozzásegíthet a visszaesések csökkenéséhez. A büntetés hatékonyságának egyik előfeltétele az elkövetett büncselekmények felderítése, továbbá, hogy az azokért felelős személyeket ténylegesen és igazságosan felelősségre vonják. Ennek része a hatékony, a negatív mellékhatásokat kizáró büntetés-végrehajtás, a társadalom aktív közremüködése a beilleszkedés segítésében, s nem utolsósorban az igazságügyi szervek tevékenységének minősége.

A büntető felelősségre vonás egyes szakaszainak hatékonyságával kapcsolatban mindenekelőtt tisztázandó, hogy elérték-e a hatóságok a szakasz lezárásával azt a célt, amelyet a törvény rendelkezései értelmében a társadalom védelme, illetve a büntetőjogi felelősségre vonás feltételeinek biztosítása érdekében megvalósítani kötelesek. A megosztott jogokat élvező és a végrehajtás folyamatában részfeladatokat teljesíteni köteles intézmények kapcsolatát rendkívül kimunkálva kell szabályozni úgy, hogy mindegyik megőrizze autonómiáját, ugyanakkor a másikkal együttmüködésre legyen késztetve. A jogalkalmazó szervezetek hatékonyságát vizsgálva a legkézenfekvőbb mutató az lehet, hogy milyen mértékben érvényesülnek a jogszabályok a jogalkalmazás során, illetve, hogy a korszerüsítésre szoruló jogintézmények átalakítása kellő időben megtörténik-e? Az eddigi kutatások túlnyomórészt a hatékonyság ellen ható tényezőket tárták fel. A hatékonyság szempontjai mindig az adott szervezet tevékenységét kifejező, az ellenőrző felügyeletet végző - illetve a külső szemlélő, az állampolgár, a közvélemény - számára is megragadható mutatókhoz igazodnak, és a statisztika adataiban jelennek meg.

A ráfordítások és a szükségletek közötti optimális viszony, az észszerüség és az áttekinthetőség, a büntetőeljárás gördülékeny gyors lefolytatása és a szankció 
kiszabása mind-mind kedvezően hatnak a büntetés hatályosulására. A büntetés hatályosulásával kapcsolatos kutatások középpontjában a börtön állt, a többi, nemcsak szabadságelvonással járó büntetéssel nemigen foglalkoztak. Már harminc éve, hogy ebben is sikerült áttörést elérni.

A nem szabadságelvonással járó szankciók sikere is föként az érvényesülésükön, azaz a végrehajtásukon múlik. Ha a végrehajtást nem szervezték meg jól, kihat az egész büntető igazságszolgáltatásra. Ha a bíróság azt látja, hogy az általa alkalmazott szankciót nem vagy nem a törvénynek megfelelően hajtják végre, nagyobb lesz a tartózkodás annak a szankciónak az alkalmazásától.

\section{AZ ELíTÉLT SZEMÉLYISÉGÉNEK SZEREPE}

A humanista filozófia, a minden ember számára elismert alapjogok és szabadságok áthatották modern társadalmainkat, és a börtönbe zárás fokozatosan a represszió másfajta jövőképének adja át a helyét - az elektronika és a kibernetika óriási fejlődésével -, a nyomon követhetőségnek. Ez az elgondolás - amely az elítélt önkéntes és tevékeny közremüködését igényli - sem választható le a felelősség tudatosításának fogalmáról, továbbá a reintegrációt szolgáló feltételektől sem határolható el. Az elektronikus felügyeletről szóló vita - mint a szabadságvesztés egyik alternatívája - Nyugat-Európában lebénulni látszik, egyrészt „a müszaki tárgy iránti csodálat” miatt, másrészt azért, mert módszeresen a „börtönnel való összehasonlítási viszonyban foglalkoznak [vele], ezért enyhébbnek tekintik, irgalmasabbnak". 6 Egyenlőtlenséget érzékeltet, és a kriminogén tényezők kiküszöbölését illetően is felveti a hatékonyság kérdését. Bár a börtönök zsúfoltsága csökkentésének egyik látványos módja, óvva intenek az elsietett bevezetésétől.

A „progresszivitás” megbecsülhetetlen filozófiává vált a büntetés-végrehajtási jogban. A fogvatartottnak lépésről lépésre kell haladnia a társadalomba való újbóli beilleszkedés során, olyannyira, hogy feltételes szabadságra bocsátása előtt az elektronikus felügyelet alá kerülésére egyre gyakrabban kerülhessen sor, de követelménnyé is válhat.

A büntetés optimális hatályosulása szorosan összefügg az elkövető személyiségével, de nem hagyható figyelmen kívül a társadalmi beilleszkedés objektív feltétele sem. A bünelkövetéstől, azaz a jogrend megsértésétől a helyreállításáig tartó hosszú utat egységes egészként mint folyamatot kell vizsgálnunk. A folyamatvizsgálat más, több, bonyolultabb, mint a rendszerszintü vizsgálat, jobban figyelembe vehetö, hogy a kriminalitás alakulásában milyen sok tényező, milyen bonyolult összefüggésben játszik szerepet. A büntetés hatékonyságának fokát

\footnotetext{
${ }^{6}$ Lásd a belga Nemzeti Kriminalisztikai és Kriminológiai Intézet kutatási jelentését (URL2).
} 
annak a szociális értéknek a különbsége adja meg, amit a büntetés szociálisan pozitív eredményeinek maximálisan lehetséges elérése jelent ahhoz az értékhez viszonyítva, amit a cél elérésére szolgáló eszközökre fordítunk.

Az elítéltre egy kiszabott büntetéssel egyidejüleg számos olyan tényező van befolyással, amely hatást gyakorolhat viselkedésének és tudatának megváltoztatására. Ilyenek elsősorban a külső környezeti feltételek, amelyeket az ember erkölcsi nézeteivel, értelmi, érzelmi, akarati tulajdonságaival összhangban adaptál, és amelyek viselkedését pozitív vagy negatív értelemben befolyásolják. Az egyes emberek még az azonos helyzetekre is másként, sokszor ellentétes módon reagálnak, amit az emberi tudat bonyolultsága egyedülálló, utánozhatatlan individualitása és relatív önállósága idéz elő.

\section{A GYAKORLATOT SEGÍTÓ KUTATÁSI TAPASZTALATOK}

A büntetés-végrehajtási intézetekben végzett kutatásom során a visszaeső elítéltek köréből 98 elítélttől kapott értékelhető válaszok szerint a visszaesési okok (egy-egy elítéltnél több ok is) főként a következők voltak: rossz baráti vagy rokoni környezet (25\%), nem dolgozott és pénzhez akart jutni (23\%), rendszeres és mértéktelen italozás (18\%), kevés kereset $(15 \%)$, a pártfogótól nem kapott segítséget $(13 \%)$, nem vették fel sehová dolgozni (10\%), pillanatnyi szükséglet kielégítése $(8 \%)$, családi életének felborulása (6\%) stb. Azt, hogy csak „benne van a hiba”, mindössze 5\%-uk mondta. A magyarázatuk arra nézve, hogy nem az ő hibájuk a visszaesés, mindig megvan. Az okok mintegy 46\%-át kifejezetten a szabadulás utáni környezetben vélték. Nem egy közülük azt hozta fel mentségére, hogy már a gyermekotthonban is farkastörvények uralkodtak, vannak erősek és gyengék, nem volt szülöhöz, testvérhez kötődés. Azt lehet tapasztalni, hogy a többszörös visszaesők társadalmi értékrendje nagyon az anyagi szempontokra helyeződött, a müveltség, a szakmai tudás nem képvisel olyan súlyt. Az alkoholt is említő 33\%-nál a szabadulás utáni környezet szintén nem elhanyagolható körülmény. Kiemelendö, hogy ugyanakkor $80 \%$-uk nem kért, és nem is kapott segítséget a szabadulása után. A jelenlegi adatgyüjtés szerint a családtagoknál, a baráti kapcsolatoknál közel ötven százalékos a kriminális háttér. A rossz gyermekkor, a fiatalkori devianciák, az állami gondozottság és a javítóintézeti elóélet kétszeres arányt eredményezett. A visszaesők között mind az alkohol, mind a kábítószer használata nagyobb részt tesz ki $(48,3 \%)$.

A büntetés végrehajtása során a visszaesés megelőzése szempontjából kiemelten fontos a normakövetési és együttmüködési hajlandóság erősítése, ezért azt speciális programokon, a jutalmak és fenyítések rendszerén túl olyan jogintézmények is támogatják Magyarországon is, mint a progresszív rezsimszabályok (Somogyvári, 2019). 


\section{ÖSSZEGZŐ GONDOLATOK}

Legyen szó akár a visszaesés elleni hatékony küzdelemről, illetve a bünismétlés veszélyének mérsékléséről, vagy az elítéltek társadalomba való visszailleszkedésének biztosításáról, a megfelelő környezeti és támogatási rendszer nélkül ez a két célkitűzés nehezen érhető el. Számolni kell az elítélés kollaterális (oldalsó, oldalági) hatásaival, amelyek alapja mind az egyéni alkalmazkodási képesség, mind pedig a személyes sebezhetőség. Az okok kiküszöbölése érdekében végzett kutatások, feltárások, vizsgálatok során széles körü figyelmet kell fordítanunk a bűn jogrendet sértő mivoltára, a megsértett jogrend helyreállításának folyamatára, az elkövető társadalomba való visszavezetésére, a tágabb értelemben vett büntető felelősségre vonás folyamatában betöltött szerepekre. Minden büntetés vagy intézkedés hatékonysága nagymértékben függ az alkalmazásától, annak milyenségétől, és az erre hivatott szervek tevékenységének színvonalától is.

A kiszabott szankció és az ember viselkedésének megváltozása közötti okozati összefüggés tehát nem feltétlenül szükségszerü, a büntetés hatásának, müködésének mechanizmusa igen bonyolult. A hatékonyság lényegében tehát a tervezett eredmények megvalósulását jelenti, a cél (generális és speciális prevenció) meghatározta tevékenység által szabályozva.

A visszaeső bünelkövetés elleni küzdelem eredményének fokozása megköveteli a módszerek és eszközök vizsgálatát, továbbfejlesztését. Valamennyi összetevő tényleges vizsgálata nélkül nehéz következtetni arra, hogy az újabb büncselekmény elkövetésében milyen mértékben játszott közre a büntetés hatástalansága vagy a szabadulás utáni körülmények.

Az újabb bűnelkövetésnek lehetnek olyan biológiai, szociálpszichológiai vagy környezeti okai, amelyek közömbösítik, lerontják a büntetés esetleges pozitív hatásait. A büntetés hatályosulása szorosan összefügg az elkövető személyiségével és kisebb mértékben a büntetési nemmel. A bünismétlés veszélyének mérséklése, az elítéltek társadalomba való visszavezetésének biztosítása nehezen érhetô el megfelelö környezeti és támogatási rendszer nélkül.

A büntető felelősségre vonás hatálya alá kerülő személy a büntetés-végrehajtási feladatot ellátó szervekkel büntetés-végrehajtási jogviszonyba kerül. E rendszer más jogágaktól eltérő életviszonyokat szabályoz.

A magyar büntetés-végrehajtási jog - mint jogi szakvizsgatárgy és egyetemi diszciplína - tudományos fogalma a következőképpen fogalmazható meg:

A büntetés-végrehajtási jog az az önálló jogág, amely a büntetések, a büntetőjogi intézkedések, a büntető eljárási törvényben felsorolt szabadságkorlátozással járó kényszerintézkedések, a szabadságkorlátozást is tartalmazó igazgatási szankciók végrehajtását; annak előkészítését, megkezdését és rendjét; a kapcsolódó járulékos feladatokat, a közremüködő szervek és személyek feladatait, a végrehajtás hatálya alatt álló személy jogi helyzetét (jogait és kötelességeit), a jogok 
és kötelességek érvényesítésének módját (büntetés-végrehajtási eljárás), a felelősségre vont személy társadalomba való visszavezetését, reintegrációját szabályozza a jogállami biztosítékrendszerrel (ügyészi törvényességi felügyelet, széles körü büntetés-végrehajtási bírói eljárás, bírósághoz és ombudsmanhoz fordulási jog, nemzetközi ellenőrzés, társadalom részvétele) teljes összhangban.

A törvényesség és humanitás követelménye, valamint a hatékonyság igénye jelentős mértékben fejleszti a büntetés-végrehajtási jogot az egész világon. Magyarországon is nagyot fejlődött a rendszerváltozás óta, vele szemben a társadalmi gyakorlat újabb és újabb követelményeket támaszt, s ez a fejlődés a büntetés-végrehajtási jog tudományági elismerése mellett annak önálló jogágiságát eredményezte.

\section{IRODALOM}

Balogh J. (1888): Börtönügyi viszonyaink reformjához. In: Magyar Jogászegyleti Értekezések 39. kötet. Budapest: Franklin Nyomda

Belovics E. (2008): A büntetés-végrehajtás ügyészi törvényességi felügyeletének szerepéröl. Börtönügyi Szemle, 1, 1-14.

Finkey F. (1933): Büntetéstani problémák. (A Magyar Tudományos Akadémia Jogtudományi Bizottságának Kiadványsorozata) Budapest

Herzog-Evans, M. (2018): Droit de l'exécution des peines 2016/2017. Dalloz, Paris

Korinek L. (2010): Kriminológia I-II. kötet. Budapest: Magyar Közlöny Lap- és Könyvkiadó

Polt P. - Vókó Gy. (2012): Az ügyészek és büntetés-végrehajtási hatóságok közötti kapcsolatok Európában. Börtönügyi Szemle, 1, 1-14.

Somogyvári M. (2019): Szervezeti müködést támogató kutatások. A büntetés-végrehajtásban fogvatartottak visszaesési kockázatainak, szerhasználati szokásainak empirikus vizsgálata. Börtönügyi Szemle, 3, 49-60.

Vókó Gy. (1996): Büntetés-végrehajtási jog. Egyetemi jegyzet. Pécs: Janus Pannonius Tudományegyetem Állam- és Jogtudományi Kar,

Vókó Gy. (1999): A magyar büntetés-végrehajtási jog. Budapest-Pécs: Dialóg Campus Kiadó

Wright, K. A. - Pratt, Travis C. - Lowenkamp, C. T. et al. (2013): The systemic model of crime and institutional efficacy: An Analysis of the Social Context of Offender Reintegration. International Journal of Offender Therapy and Comparative Criminology, 1, 92-111.

URL1: https://www.legifrance.gouv.fr/eli/loi/2009/11/24/2009-1436/jo/article_1 (letöltve 2019. november 8.)

URL2: http://nicc.fgov.be/upload/files/Overhet-NICC/2012_Ro_bert_Resume_rapport_reincarceratin.pdf (letöltve: 2018. november 8.) 